ISSN 2338-1523

E-ISSN 2541-576X

Volume 6 No. 2

Desember 2018

\title{
PEMANFAATAN TEKNOLOGI INFORMASI DALAM MANAJEMEN PENGETAHUAN BAGI PELAKU USAHA KECIL MENENGAH
}

\author{
Steffi Adam 1) \\ ${ }^{1}$ Sistem Informasi, Universitas Universal, Marina Park Kota Batam \\ email: steffiadam.ssi@gmail.com
}

\begin{abstract}
Abstrak
Tujuan dari penelitian ini adalah untuk menentukan penggunaan metode manajemen pengetahuan untuk pengusaha UKM dengan menggunakan teknologi informasi. UKM sebagai pendukung dan penyelamat ekonomi harus mampu mengelola pengetahuannya, agar dapat bersaing di era ekonomi berbasis pengetahuan. Keberadaan teknologi informasi (TI) digunakan sebagai alat dan teknik untuk menyederhanakan proses manajemen pengetahuan. Dengan adanya TI, proses manajemen pengetahuan dapat dilakukan dengan cepat, efektif dan efisien. Penelitian ini menggunakan analisis deskriptif. Sampel penelitian ini adalah 30 pengusaha UKM produksi pangan (kuliner). Dari hasil analisis deskriptif kita dapat melihat bahwa Metode dan alat manajemen pengetahuan yang melibatkan TI yang paling banyak digunakan UKM di Batam adalah alat pencarian lanjutan. Sedangkan metode dan alat-alat manajemen pengetahuan yang tidak melibatkan TI paling banyak digunakan oleh UKM di Batam adalah Peer Assist. (SA)
\end{abstract}

Kata Kunci: Manajemen Pengetahuan, Teknologi Informasi, UKM

\section{Abstract}

The purpose of this study is to determine the used of knowledge management methods for SMEs entrepreneurs by using information technology. SMEs as the support and savior of the economy should be able to manage their knowledge, in order to compete in knowledge-based economy era. The existence of information technology (IT) is used as a tool and technique to simplify the process of knowledge management. With the existence of the IT, knowledge management process can be done quickly, effectively and efficiently. This study using descriptive analysis. The samples of this research are 30 SMEs entrepreneurs of food production (culinary). From the results of the descriptive analysis we can see that Methods and tools of knowledge management involving the most widely used IT SMEs in Batam is an advanced search tools. While knowledge management methods and tools that do not involve IT most used by SMEs in Batam is a Peer Assist. (SA)

Keywords: knowledge management, information technology, SMEs

\section{PENDAHULUAN}

Memasuki era perekonomian berbasis pengetahuan, organisasi mulai berubah menjadi organisasi berbasis informasi dan menguasai pengetahuan. Organisasi mulai memikirkan cara untuk mengolah informasi dan pengetahuan agar dapat dimanfaatkan dalam melakukan operasional organisasi.
Paradigma yang terbentuk adalah organisasi yang mampu memanfaatkan informasi dan menguasai pengetahuan adalah organisasi yang unggul. Hal ini menjadikan informasi dan pengetahuan sebagai salah satu sumber daya dalam perusahaan. (Edvinsson, 2000)

Pada akhirnya pengetahuan muncul sebagai sumber daya kunci bagi organisasi. Pengetahuan didaulat menjadi sumber daya yang diprioritaskan dalam
JURSIMA

Jurnal Sistem Informasi dan Manajemen https://ejournal.stmikgici.ac.id/

STMIK GICI 
menjalankan kegiatan organisasi. Bukti praktis menyatakan dengan jelas bahwa perusahaan yang memiliki efektivitas dalam mentransfer pengetahuan memiliki tingkat kemampuan mempertahankan kelangsungan hidup organisasi yang lebih baik dan produktivitas yang lebih tinggi (Faouri, 2010). Pengetahuan berkembang menjadi sebuah aset penting dalam perusahaan.

Kebutuhan akan manajemen terhadap pengetahuan dikarenakan pengelolahan pengetahuan dapat memaksimalkan manfaat dari pengetahuan itu sendiri. Konsep dan definisi manajemen pengetahuan dikemukakan oleh para ahli seperti Voss (2002) yang menyatakan bahwa menajemen pengetahuan sebagai sistem yang memungkinkan perusahaan menyerap pengetahuan, pengalaman dan kreativitas para staf nya untuk perbaikan perusahaan, pendapat lain dikemukakan oleh Batgerson (2003) bahwa manajemen pengetahuan merupakan suatu pendekatan yang sistemik untuk mengelola aset intelektual dan informasi lain sehingga memberikan keunggulan bersaing bagi perusahaan dalam (Nawawi, 2012). Dari definisi ini terlihat bahwa manajemen terhadap perusahaan diperlukan untuk memberikan keuntungan bagi perusahaan. Dalam memanajemen pengetahuan pada masa berkembang pesatnya Teknologi Informasi (TI), membuat peranan TI tidak terlepas dalam proses memanajemen pengetahuan tersebut. Keberadaan TI membantu pengembangan dari manajemen pengetahuan. Debowski (2006) menyatakan The role of information technology (IT) in knowledge management (KM) is an essential consideration for any company wishing to exploit emerging technologies to manage their knowledge assets. Dari sini terlihat bahwa keberadaan
TI berperan penting dalam memanajemen pengetahuan.

Di Batam, UKM merupakan salah satu sektor penting pendiring pertumbuhan ekonomi, jadi sangat penting untuk meningkatkan daya saing UKM. Banyak cara yang bisa dilakukan untuk meningkatkan daya saing, salah satu nya dengan memanajemen pengetahuan yang dimiliki oleh UKM.

UKM memerlukan manajemen pengetahuan yang baik untuk keberlangsungan organisasinya. Dengan adanya manajemen pengetahuan yang baik, UKM dapat bersaing di tengah derasnya arus perekonomian yang telah berubah menjadi perekonomian berbasis pengetahuan. Persaingan dalam berbagai segi seperti produk, konsumen, pasar dan lain sebagainya. Kegagalan dalam memanajemen pengetahuan akan berdampak buruk bagi kelangsungan UKM. Oleh karena itu, manajemen pengetahuan yang baik sangat diperlukan oleh UKM.

Dari kegiatan pengamatan di lapangan terlihat bahwa pelaku UKM telah melakukan kegiatan manajemen pengetahuan untuk keberlangsungan usahanya. Kegiatan yang dilakukan seperti pengumpulan ide, berbagi pengalaman dengan sesama pelaku UKM, training karyawan baru dan juga pencarian informasi menggunakan media sosial.

Keberadaan teknologi informasi dalam manajemen pengetahuan belum maksimal. Teknologi informasi yang digunakan hanya terbatas pada bagaimana teknologi informasi dapat mempermudah pekerjaan pelaku UKM dan berkaitan dengan kegiatan rutin sehari-hari, seperti digunakan untuk menghitung pendapatan, stok/persediaan, dan pengeluaran. Penggunaan teknologi informasi belum 
terlihat maksimal pada kegiatan yang berkaitan dengan pengambilan keputusan, berbagi pengetahuan, dan pengelolaan data pelanggan.

Penelitian ini bertujuan untuk menjawab rumusan masalah yaitu: Bagaimana penggunaan teknologi informasi dalam manajemen pengetahuan? Yang didalam nya juga meliputi: 1. Metode apa saja dengan melibatkan teknologi informasi yang digunakan dalam melakukan manajemen pengetahuan? 2. Apabila tidak melibatkan teknologi informasi, maka metode apa yang digunakan dalam manajemen pengetahuan?

Ruang lingkup penelitian ini adalah penelitian ini dilakukan pada UKM yang berada di dalam wilayah Kota Batam tidak termasuk pulau-pulau yang disekitarnya. Sehingga cakupan wilayah penelitian ini berada dalam sembilan kecamatan dari dua belas kecamatan yang ada. Selanjutnya, UKM yang menjadi fokus dalam penelitian ini adalah UKM yang memiliki jenis usaha produksi dengan jenis produksi makanan.

\section{METODE PENELITIAN}

Knowledge Management (KM) atau Manajemen Pengetahuan adalah tentang bagaimana membuat pengetahuan yang tepat (right knowledge) tersedia untuk orang yang tepat. KM adalah tentang memastikan bahwa organisasi dapat belajar, dan bahwa dengan hal itu, organisasi akan dapat mengambil dan menggunakan aset pengetahuan dalam aplikasi saat ini sebagaimana yang mereka butuhkan atau dalam kata-kata Peter Drucker adalah "koordinasi dan eksploitasi sumber daya pengetahuan (knowledge resources) organisasi, dalam rangka menciptakan manfaat dan keunggulan kompetitif" (Drucker, 1995).
Definisi yang sama luas disajikan oleh Davenport (2000), yang menyatakan bahwa KM "adalah mengelola pengetahuan korporasi melalui proses sistematis dan organisasional yang ditentukan untuk memperoleh, mengatur, mempertahankan, menerapkan, berbagi dan memperbarui baik pengetahuan tacit dan eksplisit karyawan untuk meningkatkan kinerja organisasi dan menciptakan nilai."

Dari begitu banyak definisi tentang KM, Frost (2010) memberikan definisi integrasi dari beberapa definisi yang telah ada tersebut. Menurutnya KM adalah manajemen yang sistematis dari aset pengetahuan organisasi untuk tujuan menciptakan nilai dan memenuhi persyaratan taktis \& strategis; terdiri dari inisiatif, proses, strategi, dan sistem yang mempertahankan dan meningkatkan penyimpanan, penilaian, berbagi, perbaikan, dan penciptaan pengetahuan.

TI digunakan sebagai alat dan teknik untuk mempermudah proses manajemen pengetahuan. Berbagai macam jenis TI seperti telepon, email, video conference dan lain sebagainya digunakan dalam proses memanajemen pengetahuan. Dengan adanya TI ini, proses manajemen pengetahuan dapat dilakukan dengan cepat, efektif dan efisien.

Penelitian ini merupakan penelitian Kuantitatif dengan Analisis deskriptif untuk menjawab rumusan masalah yang telah dijelaskan di atas. Alat pengumpulan data yang digunakan dalam penelitian ini adalah Kuisioner.

Adapun operasional variabel dari penelitian ini adalah: 
ISSN 2338-1523

E-ISSN 2541-576X

Volume 6 No. 2

Desember 2018

Tabel 1. Operasional Metode dan Alat Manajemen Pengetahuan

\begin{tabular}{|c|c|c|c|}
\hline Variabel & Kategori & $\begin{array}{c}\text { Metode / } \\
\text { Alat }\end{array}$ & $\begin{array}{c}\text { Pilihan } \\
\text { Jawab } \\
\text { an }\end{array}$ \\
\hline \multirow{13}{*}{$\begin{array}{l}\text { Teknol } \\
\text { ogi } \\
\text { Inform } \\
\text { asi }\end{array}$} & \multirow{6}{*}{$\begin{array}{c}\text { Melibatk } \\
\text { an } \\
\text { Teknolo } \\
\text { gi } \\
\text { Informas } \\
\text { i }\end{array}$} & $\begin{array}{l}\text { Document } \\
\text { library } \\
\text { leading to } \\
\text { a document } \\
\text { manageme } \\
\text { nt system }\end{array}$ & $\begin{array}{c}\text { Ya } \\
\text { atau } \\
\text { Tidak }\end{array}$ \\
\hline & & $B \log s$ & $\begin{array}{c}\text { Ya } \\
\text { atau } \\
\text { Tidak }\end{array}$ \\
\hline & & $\begin{array}{l}\text { Social } \\
\text { media }\end{array}$ & $\begin{array}{c}\text { Ya } \\
\text { atau } \\
\text { Tidak }\end{array}$ \\
\hline & & $\begin{array}{l}\text { Voice dan } \\
\text { Video Over } \\
\text { Internet } \\
\text { Protocol }\end{array}$ & $\begin{array}{c}\text { Ya } \\
\text { atau } \\
\text { Tidak }\end{array}$ \\
\hline & & $\begin{array}{l}\text { Advanced } \\
\text { search } \\
\text { tools }\end{array}$ & $\begin{array}{c}\text { Ya } \\
\text { atau } \\
\text { Tidak }\end{array}$ \\
\hline & & $\begin{array}{l}\text { Building } \\
\text { knowledge } \\
\text { cluster }\end{array}$ & $\begin{array}{c}\text { Ya } \\
\text { atau } \\
\text { Tidak }\end{array}$ \\
\hline & \multirow{7}{*}{$\begin{array}{c}\text { Tanpa } \\
\text { melibatk } \\
\text { an } \\
\text { Teknolo } \\
\text { gi } \\
\text { Informas } \\
\text { i }\end{array}$} & $\begin{array}{l}\text { Brainstrom } \\
\text { ing }\end{array}$ & $\begin{array}{c}\text { Ya } \\
\text { atau } \\
\text { Tidak }\end{array}$ \\
\hline & & $\begin{array}{l}\text { Learning } \\
\text { and idea } \\
\text { capture, }\end{array}$ & $\begin{array}{c}\text { Ya } \\
\text { atau } \\
\text { Tidak }\end{array}$ \\
\hline & & Peer Assist & $\begin{array}{c}\text { Ya } \\
\text { atau } \\
\text { Tidak }\end{array}$ \\
\hline & & $\begin{array}{l}\text { Learning } \\
\text { Review }\end{array}$ & $\begin{array}{c}\text { Ya } \\
\text { atau } \\
\text { Tidak }\end{array}$ \\
\hline & & $\begin{array}{l}\text { After } \\
\text { Action } \\
\text { Review, }\end{array}$ & $\begin{array}{c}\text { Ya } \\
\text { atau } \\
\text { Tidak }\end{array}$ \\
\hline & & Storytelling & $\begin{array}{c}\text { Ya } \\
\text { atau } \\
\text { Tidak }\end{array}$ \\
\hline & & $\begin{array}{l}\text { Collaborati } \\
\text { on }\end{array}$ & $\begin{array}{c}\text { Ya } \\
\text { atau } \\
\text { Tidak }\end{array}$ \\
\hline
\end{tabular}

\begin{tabular}{|l|l|l|c|}
\hline & $\begin{array}{l}\text { Physical } \\
\text { Workspace }\end{array}$ & \\
\cline { 3 - 4 } & $\begin{array}{l}\text { Knowledge } \\
\text { Caf }\end{array}$ & $\begin{array}{c}\text { Ya } \\
\text { atau } \\
\text { Tidak }\end{array}$ \\
\hline
\end{tabular}

Populasi dalam penelitian ini adalah UKM di Kota Batam yangn memenuhi persyaratan:

1. Usaha telah berjalan minimal 6 bulan.

2. Telah menerapkan Manajemen pengetahuan dalam usaha yang dijalankan.

Berdasarkan data yang diperoleh dari Dinas Koperasi, Pasar dan Usaha Menengah dan Mikro Kota Batam tahun 2014 terdapat 1006 pelaku UKM di Kota Batam. UKM tersebut terbagi dalam sembilan jenis usaha diantaranya, aneka usaha, industri, jasa, perdagangan, perikanan, perkebunan, pertanian, peternakan dan produksi yang tersebar di dua belas kecamatan se Kota Batam.

Dari data yang diperoleh terdapat 286 pelaku UKM. Dari 286 UKM yang terdaftar yang usaha nya masih berjalan minimal 6 bulan adalah sebanyak 153 UKM. Dari 153 UKM yang dalam menjalankan usahanya melakukan kegiatan manajemen pengetahuan yang dibantu dengan teknologi informasi, baik untuk pelaku UKM dalam hal ini owner/pemilik ataupun kepada karyawan adalah sebanyak 56 UKM.

Berdasarkan data populasi yang telah dijelaskan, maka teknik pengambilan sampel adalah teknik sensus dengan jumlah responden 30 pelaku UKM.

HASIL DAN PEMBAHASAN 
Responden penelitian ini adalah pelaku Usaha Kecil dan Menengah (UKM) dengan jenis usaha produksi makanan di Kota Batam. Kuisioner disebarkan pada waktu yang telah ditentukan sesuai dengan jadwal penelitian yaitu bulan September 2014 sampai dengan Januari 2015. Adapun jumlah responden yang mengisi kuisioner sebanyak 30 responden. Dari hasil pengisian kuisioner maka didapat profil responden sebagai berikut:

1. Berdasarkan Jenis Usaha

Jenis usaha yang dijalankan oleh responden yang mengisi kuisioner $100 \%$ atau sebanyak 30 usahanya termasuk usaha kecil.

2. Berdasarkan Bentuk Usaha

Pada penelitian ini bentuk usaha yang dijanlankan oleh responden adalah sebagai berikut:

a. Responden yang usahanya berbentuk CV sebanyak 8 usaha.

b. Responden yang usahanya berbentuk PT sebanyak 0 usaha. c. Responden yang usahanya berbentuk lainnya sebanyak 22 usaha.

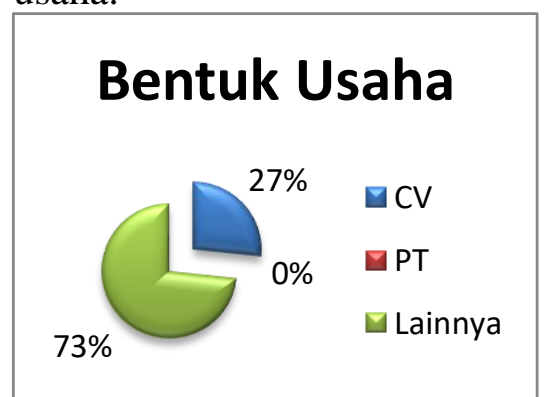

Gambar 1 Pie Chart Bentuk Usaha

Dari data ini dapat dilihat bahwa bentuk Usaha lainnya memiliki presentasi terbesar yaitu $73 \%$. Bentuk usaha lainnya ini berupa Usaha yang berbadan hukum domisili usaha rumahan.
3. Berdasarkan Jabatan

Sebanyak 30 responden atau $100 \%$ responden yang mengisi kuisioner adalah pemilik atau owner dari setiap usaha yang berjalan.

4. Berdasarkan Usia

Profil responden penelitian berdasarkan usia adalah sebagai berikut:

a. Responden yang berusia $<25$ tahun sebanyak 2 usaha.

b. Responden yang berusia 25-35 tahun sebanyak 15 usaha.

c. Responden yang berusia $>35$ tahun sebanyak 13 usaha.

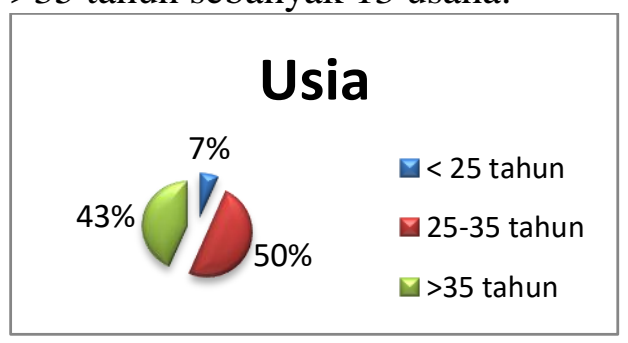

Gambar 2 Pie Chart Usia

Dari data ini dapat dilihat bahwa Usia memiliki presentasi terbesar yaitu 25-35 tahun. Hal ini menunjukkan bahwa sebagian besar pemilik berada di usia produktif

5. Berdasarkan Jenis Kelamin Profil responden penelitian berdasarkan jenis kelamin adalah sebagai berikut:

a. Responden yang berjenis kelamin laki-laki sebanyak 8 responden.

b. Responden yang berjenis kelamin perempuan sebanyak 22 responden. 


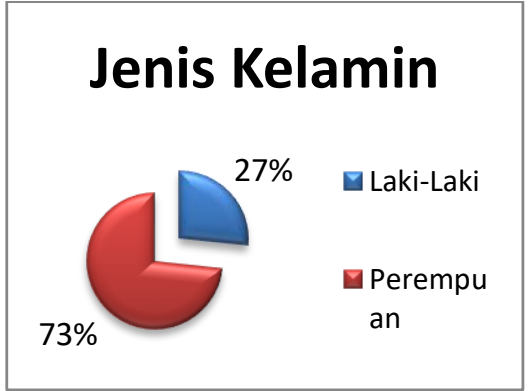

Gambar 3 Pie Chart Jenis Kelamin

Dari data ini dapat dilihat bahwa jenis kelamin perempuan memiliki presentasi terbesar yaitu 73\%. Hal ini dikarenakan sebagian besar pemilik adalah Ibu Rumah Tangga.

6. Berdasarkan Pendidikan Terakhir

Profil reponden penelitian berdasarkan pendidikan terakhir adalah sebagai berikut:

a. Responden yang berpendidikan terakhir SMA sebanyak 9 orang

b. Responden yang berpendidikan terakhir $\mathrm{S} 1$ sebanyak 4 orang

c. Responden yang berpendidikan terakhir lainnya sebanyak 17 orang

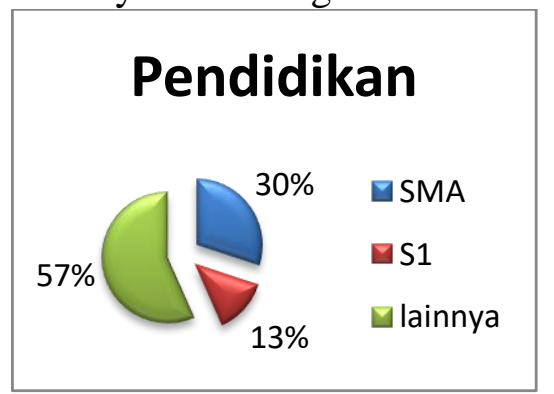

Gambar 4 Pie Chart Pendidikan Terakhir

Dari data ini dapat dilihat bahwa jenjang pendidikan lainnya yang memiliki presentasi terbesar yaitu
57\%. Menurut hasil pengamatan pendidikan lainnya meliputi D3 dan di bawahnya.

\section{Penggunaan Teknologi Informasi dalam Manajemen Pengetahuan}

Metode dan alat dalam manajemen pengetahuan dibagi menjadi dua bagian yaitu yang melibatkan teknologi informasi maupun yang tidak menggunakan teknologi informasi. Pada penelitian ini, metode dan alat yang menggunakan teknologi informasi terdiri dari 6 cara yaitu melalui document library leading to a document management system, blogs, social media, Voice dan Video Over Internet Protocol, advanced search tools dan building knowledge cluster.

\section{IT Method Knowledge...}

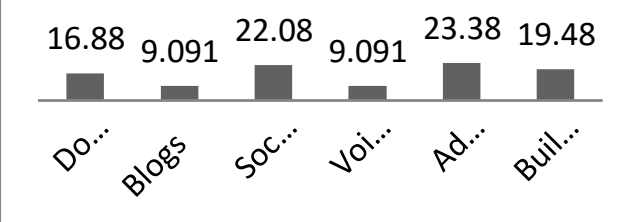

Gambar 5 IT Method Knowledge

\section{Management}

Berdasarkan hasil penelitian seperti tertera pada gambar 4.1, sebanyak 16,88\% pelaku UKM di Kota Batam sudah menggunakan document library leading to a document management system, kemudian sebanyak $9,09 \%$ sudah menggunakan blogs, sebanyak 22,08\% menggunakan social media, sebanyak 9,09\% menggunakan Voice dan Video Over Internet Protocol, 23,38\% menggunakan advanced search tools dan sebanyak 19,48\% menggunakan building knowledge cluster. Dari keenam metode yang digunakan, penggunaan advanced search tools memiliki persentase paling 
tinggi yaitu sebesar 23,38\%. Penggunaan advanced search tools meliputi penggunaan mesin pencari seperti google, yahoo, bing untuk mencari informasi/pengetahuan.

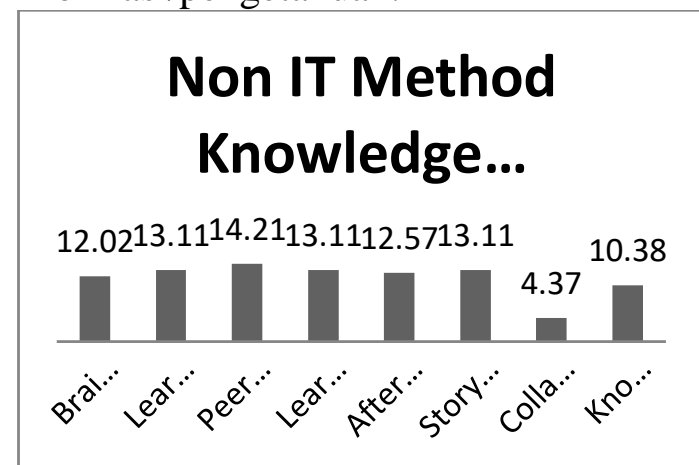

Gambar 6 Non IT Method Knowledge Management

Selain melibatkan teknologi informasi, penerapan manajemen pengetahuan juga dilakukan tanpa melibatkan teknologi informasi. Pada penelitian ini, teradapat delapan metode yang digunakan dalam manajemen pengetahuan yaitu brainstroming, learning and idea capture, peer assist, learning review, after action review, storytelling, collaboration physical workspace dan knowledge cafe.

Dari delapan metode yang diteliti pelaku UKM yang telah melakukan brainstroming sebesar $12,02 \%$, learning and idea capture sebesar $13,11 \%$, peer assist sebesar $14,21 \%$, learning review sebesar $13,11 \%$, after action review sebesar 12,57\%, storytelling sebesar $13,11 \%$, collaboration physical workspace sebesar 4,37\% dan knowledge cafe sebesar 10,38\%. Peer Assist merupakan kegiatan yang memiliki presentase tertinggi yaitu $14,21 \%$ dibanding dengan metode yang lainnya. Peer Assist merupakan proses mengumpulkan pengetahuan dengan bertanya sebelum mengerjakan suatu proyek kepada rekan-rekan yang lebih berpengalaman dan berkompetensi di bidangnya.

Berikut adalah penjelasan masing-masing metode, alat dan teknik tersebut:

1. Brainstorming, merupakan cara sederhana untuk membantu sekelompok orang untuk menghasilkan ide baru maupun ide yang tidak biasa (kreatif). Proses ini sebenarnya dibagi menjadi dua frase yaitu divergensi dan konvergensi. Selama fase divergensi, semua orang setuju untuk menunda penilaian mereka. Dengan kata lain, semua ide akan dianggap valid. Selama frase konvergen, para peserta menggunakan penilaian merekaa yang positif, mereka mencari apa yang mereka sukai hingga mereka menemukan kelemahan dari ide mereka.

2. Learning and Idea Capture, Sebuah aspek kunci dari manajemen pengetahuan (KM), di tingkat pribadi dan tim, adalah untuk lebih 'kolektif dan sistematis' menangkap pembelajaran dan ide-ide yang sedang berlangsung. Sedang pembelajaran dan pengambilan gagasan adalah panduan tentang cara untuk melakukan ini.

3. Peer Assist, Ini adalah teknik yang digunakan oleh tim proyek untuk meminta bantuan dari rekan-rekan dan subjek ahli materi mengenai masalah yang signifikan tim yang dihadapi. Membantu rekan merupakan bagian dari proses apa yang disebut British Petroleum (BP) 'belajar sebelum melakukan ', yaitu, mengumpulkan pengetahuan sebelum memulai suatu proyek atau bagian dari pekerjaan. rekan yang Membantu pertemuan biasanya berlangsung dari setengah hari untuk 2 hari. Kedua tim proyek dan 
rekan membahas proyek dan potensi masalah/perhatian dan memberikan solusi. Keuntungan tim wawasan proyek dari rekan-rekan mereka di pertemuan. Rekan-rekan dapat belajar dalam proyek satu dengan yang lain.

4. Learning Reviews, Ini adalah teknik yang digunakan oleh tim proyek untuk membantu tim dan pembelajaran individu selama proses kerja. Learning Review berbeda dari Active Action Review (AAR). Sebuah AAR biasanya dilakukan pada akhir proyek formal. Hal ini dapat dilakukan setelah acara diidentifikasi. Sebuah acara dapat berupa seluruh kecil tindakan atau bagian diskrit dari aksi yang lebih besar, misalnya, pertemuan perencanaan proyek.

5. After Action Review, Merupakan teknik untuk mengevaluasi dan pengambilan pelajaran pada penyelesaian proyek. Hal ini memungkinkan anggota tim proyek untuk menemukan sendiri apa terjadi, mengapa hal itu terjadi, dan bagaimana mempertahankan kekuatan dan memperbaiki kelemahan. Hal ini disusun sebagai diskusi informal dengan anggota tim utama dari proyek ini. Sebuah AAR juga dapat dilakukan setelah selesainya proyek atau pada pencapaian setiap tonggak kunci dari proyek-durasi yang panjang. Ini bukan kritik atau sesi keluhan. AAR memaksimalkan pembelajaran dengan menawarkan platform bagi para pemimpin dan anggota untuk jujur berbicara tentang proyek. Ini bukan skala penuh laporan evaluasi.

6. Storytelling, Dalam konteks KM, sejak awal, bercerita telah digunakan sebagai cara yang ampuh untuk berbagi dan mentransfer pengetahuan, terutama pengalaman dan pengetahuan tacit.
Secara harfiah menceritakan cerita: seseorang yang memiliki pengetahuan yang berharga menceritakan kisah / pengalaman di depan orang-orang yang ingin mendapatkan pengetahuan. Meskipun metode ini cukup sederhana, bercerita-saat itu tepat dilakukanmampu berbagi tingkat yang jauh lebih dalam dari sekedar pengetahuan berbagi Informasi. Mendongeng memiliki daya yang kuat untuk berbagi pengalaman seseorang dan pelajaran karena cerita yang efektif dapat menyampaikan konteks yang kaya bersama dengan isi.

7. Collaborative Physical Workspace, Ketika kita berbagi atau menciptakan pengetahuan, kita biasanya berinteraksi dengan orang lain melalui tatap muka komunikasi kita bahas, dialog, atau hanya hanya mengajukan pertanyaan. Ruang kerja fisik di mana interaksi manusia seperti terjadi-dan dapat mendukung pengetahuan berbagi / penciptaan jika yang dirancang dengan baik. Anda mungkin berpikir, "Kami memiliki meja untuk semua orang, ruang pertemuan untuk rapat internal, dan ruang untuk bicara bisnis. Apa lagi yang kita butuhkan? " Sebenarnya, ruang kerja fisik bekerja lebih dari itu.

\section{APO Knowledge Management} Assessment Tool, Ini adalah kuesioner survei yang dirancang untuk membantu organisasi melakukan awal dan cepat penilaian kesiapan untuk Knowledge Management (KM). Penilaian tersebut dilakukan pada awal program KM. Sebelum mulai perjalanan KM, organisasi perlu untuk mengetahui kekuatan dan peluang untuk perbaikan. Organisasi kemudian dapat fokus pada program KM untuk mengatasi 
kesenjangan yang diidentifikasi melalui penilaian.

9. Knowledge Café, Sebuah cafe pengetahuan adalah cara untuk memiliki diskusi kelompok, untuk mencerminkan, dan untuk mengembangkan dan berbagi pikiran dan wawasan yang akan muncul, dalam cara yang sangat non-konfrontatif. Sebuah cafe pengetahuan menunda semua penilaian dan biasanya mengarah untuk mengembangkan wawasan yang lebih dalam dan berbagi dari biasa.

10. Community of Practice, COP adalah kelompok masyarakat yang memiliki kepedulian atau gairah untuk sesuatu yang mereka lakukan, dan belajar bagaimana melakukannya dengan lebih baik saat mereka berinteraksi secara teratur. Dalam konteks KM, COP adalah terbentuksengaja atau spontan-untuk berbagi dan menciptakan keterampilan umum, pengetahuan, dan keahlian di antara karyawan.

11. Taxonomy, sebuah taksonomi adalah teknik yang menyediakan struktur untuk mengatur informasi, dokumen, dan perpustakaan dengan cara yang konsisten. Struktur ini membantu orang untuk secara efisien menavigasi, menyimpan, dan mengambil data dan informasi di seluruh organisasi dibutuhkan. Membangun alur kerja alami dan pengetahuan kebutuhan dalam struktur intuitif. Taksonomi dapat dianggap sebagai sistem klasifikasi, yaitu, 'The Daftar Isi' untuk modal pengetahuan organisasi. Taksonomi juga menyediakan pointer ke berbasis manusia keahlian dan pengetahuan. Sebuah taksonomi biasanya mencakup:
Hirarki dilayari konsep dan istilah, dan Informasi "tag" yang mengidentifikasi lebih lanjut dan mengkategorikan elemen konten. Taksonomi juga dapat mencakup pelabelan metadata, yang memungkinkan data primer atau informasi secara sistematis dikelola dan dimanipulasi. Hasil metadata ini dalam struktur hirarkis, yang jika dilakukan dengan benar, tidak hanya memungkinkan pemetaan oleh potongan kata tetapi juga memungkinkan pemetaan dengan konsep dan kesimpulan.

12. Document Libraries leading to a Document Management System, dari ilmu Manajemen Informasi, dan dari ilmu-ilmu perpustakaan, kami selalu tertarik informasi yang lebih baik dan manajemen dokumen. Efisien dan efektif akses ke dokumen adalah penawar 'informasi yang berlebihan'. Mempertahankan 'dokumen repositori 'dengan kategorisasi yang baik dan / atau taksonomi dan metadata (link ke ini nanti) adalah terpenting untuk pengajuan dan, kemudian, mencari dan menemukan informasi yang tepat di waktu yang tepat.

13. Knowledge Bases (Wikis, etc.), dalam konteks manajemen pengetahuan organisasi (KM), kita harus mengeksternalisasi pengetahuan penting atau kritis yang perlu diakses, bersama, diterapkan, dan dikembangkan oleh lain. Tapi KM tentu harus tidak menjadi sekitar eksternalisasi dan kodifikasi sebanyak pengetahuan mungkin. Itu hanya tidak mungkin dan tidak efektif. Kita harus mempertimbangkan kodifikasi yang pengetahuan yang dianggap 'kritis' untuk mengembangkan dan menerapkan dalam organisasi dan akan 
membuat 'perbedaan besar' untuk kinerja organisasi. Di sinilah kita dapat secara efektif membuat eksplisit 'basis pengetahuan'. Ini tentu saja merupakan ide yang baik untuk pertama mengidentifikasi 'bidang pengetahuan kunci' dalam organisasi itu, jika dikelola dengan baik, akan benar-benar membuat perbedaan besar untuk kinerja. Sebagai pedoman, untuk masing-masing bidang pengetahuan utama yang diidentifikasi, adalah praktek KM yang baik untuk mengembangkan basis pengetahuan (untuk mempertahankan pengetahuan eksplisit kritis) dan juga komunitas praktek / minat atau pengetahuan Jaringan di sekitar daerah ini kunci pengetahuan (ke permukaan dan mentransfer pengetahuan tacit).

14. Blogs, Blog adalah situs 'gaya jurnal' sangat sederhana yang berisi daftar entri, biasanya secara terbalik urutan kronologis. Entri biasanya artikel pendek atau cerita, sering berkaitan dengan saat ini peristiwa. Namun, entri tidak harus hanya teks biasa. Mereka juga bisa menjadi foto, video, rekaman audio, atau campuran dari semua jenis. Isi dari blog dapat dibuat oleh seorang penulis tunggal atau, dalam kasus beberapa lebih blog populer, seluruh koleksi penulis. Meskipun situs web apapun bisa menyebut dirinya sebuah blog, ada beberapa fitur yang umumnya ditemukan di blog. ini adalah 1. Isi pada dasarnya linear. Cerita, dan item, yang ditambahkan ke daftar tumbuh, dan pembaca dapat menelusuri daftar untuk melihat bagaimana penulis (s) pengalaman telah dikembangkan. 2 . blog memiliki fokus. Hal ini ditafsirkan sangat liberal-orang blog mengembara di berbagai macam topik-tapi bahkan ketika melampaui batas, biasanya ada beberapa pengertian bahwa blog adalah tentang sesuatu. 3. blog ini memiliki mekanisme yang pembaca dapat mengomentari item. beberapa blog situs memilih untuk tidak mengaktifkan fitur ini. Namun, diskusi pasti salah satu yang paling aspek manfaat blogging, meskipun memungkinkan juga cenderung menempatkan beban yang lebih besar pada penulis karena komentar biasanya perlu 'moderator'. 4. Blog menerbitkan indeks elektronik yang memungkinkan orang untuk secara otomatis sadar ketika sesuatu yang baru telah ditambahkan.

15. Social Network Services, Sebuah jaringan sosial adalah sekelompok orang yang memiliki area umum yang menarik. jejaring sosial layanan sistem online yang mendukung jejaring sosial. Layanan inti yang mereka tawarkan biasanya digunakan, menemukan orang-orang yang memiliki kepentingan atau kebutuhan yang sama; menggabungkan orang menjadi kelompok-kelompok, atau subkelompok, dan mampu berkomunikasi dengan kelompokkelompok; dan Sharing konten, seperti dokumen link ke situs yang relevan, atau bahkan mengalir video.

16. Voice and Voice-over-Internet Protocol (VOIP), dalam istilah yang sangat sederhana, internet kini mampu mengirim kedua sinyal audio dan video antara komputer, menggunakan tidak lebih dari koneksi broadband dan beberapa murah peralatan, seperti webcam dan headset. Kemampuan ini sering disebut sebagai Voice Over Internet Protocol (VOIP). Penerapan broadband telah menyebabkan 
terciptanya sejumlah perusahaan yang menawarkan berbagai Layanan VOIP. Secara umum, mereka semua menawarkan instant messaging dan transmisi suara; banyak mereka menyediakan panggilan video juga. Biaya layanan bervariasi dari perusahaan ke perusahaan. Namun, hampir semua penyedia menawarkan gratis komputer-ke-komputer audio; banyak dari mereka menyediakan panggilan video gratis satu-ke-satu.

17. Advanced Search Tools, Hampir semua orang yang telah menggunakan World Wide Web, di beberapa titik telah menggunakan pencarian mesin. Namun, sangat sedikit pengguna mengambil keuntungan dari alat pencarian lanjutan yang yang ditawarkan oleh sebagian besar mesin pencari. Memahami alat ini dapat menghasilkan signifikan peningkatan kualitas hasil pencarian.

18. Building Knowledge Clusters, Istilah 'Pengetahuan Cluster' adalah istilah yang diberikan kepada kelompok yang-akibat datang bersama-sama dalam baru cara-membuat, berinovasi, dan menyebarkan pengetahuan baru. Dengan kata lain, yang berbeda individu, tim, dan organisasi sekarang dapat datang bersama-sama, hampir, di Internet, untuk lebih baik berkomunikasi, berkolaborasi, belajar, dan berbagi pengetahuan melalui cluster. Istilah ini digunakan, misalnya, untuk mewakili sekelompok perusahaan di sektor industri yang sama, misalnya, teknologi tinggi klaster pengetahuan, bioteknologi pengetahuan klaster. Ada Cluster Pengetahuan Daerah di mana kelompok-kelompok organisasi datang bersama-sama, terlepas dari ukuran mereka, sekitar topik tertentu. Seringkali, ada insiden tinggi inovasi pusat terkait dengan universitas lokal. Di pusat cluster, biasanya ada penelitian dan pengembangan $(\mathrm{R} \& \mathrm{D})$ dan topik lembaga penelitian inti umum dengan potensi tinggi penelitian. Sistem ini juga dapat melibatkan partisipasi organisasi dan kelompok lain baik dari dalam dan luar wilayah atau wilayah. Sebuah Cluster Pengetahuan dapat dilihat sebagai jenis Community of Practice (COP). Sebuah Pengetahuan Cluster adalah COP lebih fokus, biasanya dengan tujuan menggabungkan sumber pengetahuan untuk menciptakan produk baru yang inovatif dan layanan dan / atau mengatur dan berkompetisi dengan cara baru untuk menang kontrak bisnis yang lebih besar.

19. Expert Locator, adalah sebuah teknologi informasi (TI) alat untuk mengaktifkan penggunaan yang efektif dan efisien dan / atau berbagi pengetahuan yang ada dengan menghubungkan orang-orang yang membutuhkan pengetahuan dan orangorang yang memiliki pengetahuan tertentu. Kadang-kadang, sistem ini membantu membangun tim baru / proyek dengan mencari berbagai keahlian yang dibutuhkan. Keahlian Locator dapat halaman kuning sederhana elektronik, sistem yang lebih canggih untuk secara otomatis mencari keahlian, atau bahkan campuran IT dan orang-orang (yang sering disebut Pengetahuan Broker) yang mendukung menemukan dan menghubungkan orang yang ingin pengetahuan dan orang yang memiliki pengetahuan. 
20. Collaborative Virtual Workspaces, Inti dari sebuah ruang kerja virtual kolaboratif adalah bahwa hal itu memungkinkan orang untuk bekerja bersama-sama, terlepas dari mana mereka berada secara fisik. Secara praktis, ini berarti bahwa harus melibatkan kombinasi sharing dokumen, mengedit kolaboratif, dan audio / video conferencing. Meskipun pemasok menawarkan paket perangkat lunak yang mengandung semua elemen, banyak pengguna merakit koleksi mereka sendiri alat yang memenuhi kebutuhan spesifik mereka.

\section{SIMPULAN}

Berdasarkan penelitian dan pengolahan data yang telah dilakukan sesuai dengan metode yang dijelaskan maka dapat disimpulkan hal-hal sebagai berikut:

1. Penggunaan advanced search tools adalah metode manajemen pengetahuan dengan melibatkan teknologi informasi yang paling besar presentase penggunaannya

2. Peer Assist adalah metode manajemen pengetahuan tanpa melibatkan teknologi yang paling besar presentase penggunaannya bagi pelaku UKM di Kota Batam.

Saran yang dapat diberikan adalah sebagai berikut:

1. Karena keterbatasan ruang lingkup dari penelitian ini yaitu UKM dengan jenis usaha produksi makanan, maka diharapkan bagi peneliti lain dapat melakukan studi lanjut berkaitan dengan UKM dengan jenis usaha lainnya.

2. Untuk penelitian selanjutnya, juga dapat diteliti mengenai jenis manajemen pengetahuan apa yang harus diterapkan bagi UKM dengan jenis produksi makanan agar dapat menjadikan manajemen pengetahuan sebagai alat strategis guna meningkatkan kinerja dan pengembangan UKM dengan jenis produksi makanan untuk kedepan nya. Selanjutnya untuk penelitian selanjutnya juga dapat diteliti mengenai teknologi informasi yang bagaimana yang dapat membantu UKM dengan produksi makanan untuk meningkatkan pengelolaan manajemen pengetahuan agar menunjang pertumbuhan dan perkembangan UKM dengan jenis produksi makanan.

\section{UCAPAN TERIMA KASIH}

Terima kasih penulis ucapkan kepada seluruh pihak yang telah membantu dalam penelitian ini terutama para pelaku UKM yang bersedia menjadi responden dalam penelitian ini.

\section{DAFTAR PUSTAKA}

Davenport, Thomas $\mathrm{H}$. and Lawrence Prusak (2000) "Working Knowledge: How Organizations Manage What They Know", ACM: Ubiquity - Working Knowledge: How Organizations Management

Debowski, S 2006, Knowledge Management, John Wiley \& Sons, Milton, Queensland, Australia.

Drucker P.F. (1995) Managing in a Time of Great Change, Butterworth-Heinemann Ltd, Oxford

Edvinsson, L. (2000) Some perspectives on intangibles and intellectual capital 2000. Journal of Intellectual Capital, Vol. 1, No.1, pp. 12-16

Faouri, Al Abeer Hmoud, 2010. A Supportive Knowledge Sharing Climate To Enable IT/Business Strategic Alignment (An Empirical Study on The 
ISSN 2338-1523

E-ISSN 2541-576X

Volume 6 No. 2

Desember 2018

Telecommunications Sector in Jordan).

Nawawi, Ismail. 2012. Manajemen Jordan Journal of Business Pengetahuan (Knowledge Management): Administration. Vol. 6, No 1, pp 119-140 Frost,.Alan M.Sc., (2010, update 2013), "Defining Knowledge, Information, Data", http://www.knowledge-managementtools.net/. Diakses 24 Agustus 2014

Teori dan Aplikasi dalam Mewujudkan Daya Saing Organisasi Bisnis dan Publik. Ghalia Indonesia. Jakarta. ISBN 9789794506240
JURSIMA

Jurnal Sistem Informasi dan Manajemen https://ejournal.stmikgici.ac.id/ STMIK GICI 